INTRODUCTION TO VALUATION 


\section{INTRODUCTION TO VALUATION}

\section{SECOND EDITION}

\section{DAVID RICHMOND, F.R.I.C.S,F.S.V.A.}

Principal Lecturer in Valuation,

Department of Surveying,

Trent Polytechnic,

Nottingham

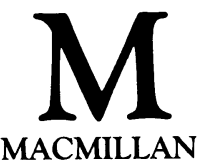


(C) D. Richmond 1975,1985

All rights reserved. No part of this publication may be reproduced or transmitted, in any form or

by any means, without permission

First edition 1975

Reprinted 1978, 1979, 1981, 1982, 1983

Second edition 1985

Published by

Higher and Further Education Division

MACMILLAN PUBLISHERS LTD

Houndmills, Basingstoke, Hampshire RG21 2XS and London

Companies and representatives

throughout the world

ISBN 978-0-333-38437-4 ISBN 978-1-349-07690-1 (eBook)

DOI 10.1007/978-1-349-07690-1 


\section{CONTENTS}

Preface to the First Edition

Preface to the Second Edition

viii

ix

1 The Concept of Valuation 1

The Function of the Valuer $\quad 1$

The purchase and sale of property - The letting of property - The granting of mortgage facilities - Rating, insurance, taxation and other specialised purposes

Factors Affecting the Value of Property

The Purpose of Valuation Tables

2 The Mathematics of Valuation 7

Arithmetical Progressions $\quad 7$

Geometrical Progressions 9

Simple Interest $\quad 11$

Compound Interest $\quad 14$

Mortgage Repayments $\quad 16$

$\begin{array}{ll}\text { Depreciation } & 18\end{array}$

3 Principles and Sources of Investment 21

The Investment Market $\quad 22$

Sources of Investment $\quad 22$

Banks and building societies - Stocks and shares -

Unit trusts - Land and property

Yield and Dividend

4 Land and Property as an Investment 27

$\begin{array}{ll}\text { Legal Estates } & 27\end{array}$

Equitable interests

Controls on Land Usage $\quad 30$

Private control 
Statutory Controls

Planning control - Building and other controls

Characteristics of Land and Property

External influences - Deterioration of the structure -

Changes in taste and demand - Effect of adjacent

activities - Economic activities - Changes in legislation -

Inflation - Relationship to other investment sources -

Costs of transactions

Determination of Rental Value

Rent and Capital Value

Outgoings

Rent payable to a superior landlord - Repairs - Insurances -

Management - Landlord's services - Bad debts and

voids - Tithe redemption annuity - Rent charges -

General and water and sewerage rates

Characteristics of Different Types of, and Interests in, Property

Ground rents - Agricultural land - Residential prop-

erties - Shops - Offices - Industrial premises - Other

types of property

Patterns of Yields

5 Construction and Analysis of Valuation Tables

Single Rate Tables

Amount of $£ 1$ (A) - Present Value of $£ 1$ (PV) - The

Amount of $£ 1$ per annum - Annual Sinking Fund (s) -

Years' Purchase (YP) or present value of $£ 1$ per annum -

Years' Purchase in perpetuity (YP) - Years' Purchase of

a reversion to a perpetuity - Interest at intervals of less

than one year - Income to be received at intervals of

more than one year

Dual Rate Tables

Years' Purchase or present value of $£ 1$ per annum (YP) -

The effect of tax on the sinking fund element of the

dual rate YP - The annuity $£ 1$ will purchase

Mortgage Instalment Table

Valuation Formulae and their Inter-relationship

Adjustment of Formulae for Incomes other than

Annually in Arrears 
Freehold Interests

Perpetual income - Varying and deferred incomes

Fixed income for the period of the lease - Varying and deferred incomes during the period of the lease - Nontax-paying investors

Profit Rent

Premiums

Calculation of the premium or reduction in rent

Combined Freehold and Leasehold Valuations

Double Sinking Fund

7 Methods of Valuation

The Investment Method

The Comparison Method

The Residual Method

The Profits or Accounts Method

The Reinstatement Method

130

The Contractor's Method

8 Discounted Cash Flow Techniques

Net Present Value

Internal Rate of Return

9 Inflation and Growth

Valuation methods - Constant rent - Bibliography 


\section{PREFACE TO THE FIRST EDITION}

The main purpose of this book is to assist those studying the subject of valuation for the Part 1 Examination of the Royal Institution of Chartered Surveyors and other relevant professional bodies, and for degrees and diplomas in estate management at universities and polytechnics. I also hope that it will be helpful to quantity, building and mineral surveying students, who require a knowledge of valuation in their studies, and others interested in the principles and techniques of property valuation.

Most examinations in valuation contain a number of questions involving calculations. In this connection the reader may benefit from attempting the questions included in chapters $3,6,7$ and 8 , the answers being provided at the end of the book. The chapter on mathematical aids should be of value for purposes of revision.

When answering questions with tax implications, the reader should apply the tax rates current at the time. I have used different tax rates throughout the book, so that the reader will appreciate that tax rates can vary according to the differing financial and personal circumstances of investors, and Finance Act changes.

I would like to express my thanks to $\operatorname{Dr} I$. H. Seeley for his invaluable advice and encouragement; also to many other colleagues at Trent Polytechnic for their helpful comments.

Sincere thanks are also due to the Royal Institution of Chartered Surveyors and the Universities of London and Reading for permission to use past examination questions as examples and test questions. 


\section{PREFACE TO THE SECOND EDITION}

It is nine years since the First Edition of this book appeared, and during that time there has been considerable developments in valuation techniques and research.

In this edition I have taken out my original chapter on mathematical aids, due to the widespread use of calculators. I have updated the main text and extended chapter 5 (originally chapter 6 ) to take account of payments receivable other than annually in arrears.

Two new chapters have been produced on discounted cash flows and allowing for inflation and growth.

I have received helpful comments from both my students and my colleagues at Trent Polytechnic, for which I am very grateful. I would especially like to thank my 'partner' in valuation teaching, Neil Crosby, for his assistance in the preparation of chapter 9.

I would also like to thank Professor Ivor H. Seeley, the Series Editor, for his continued encouragement and assistance.

In the preface to the First Edition, I omitted to thank my mother for her help with proof-reading and indexing. I can now rectify this and thank her, rather belatedly! 